\title{
Family Law: Order Out of Chaos
}

\author{
Barbara N. Armstrong*
}

One hesitates to plead for reforms in the name of common sense ... for we belong to a profession that prides itself on not throwing chaos lightly to the reinds. $\dagger$

TN THE IONG SERIES of constructive opinions written by Chief Justice 1 Traynor in the area of family law two, Perez v. Sharp $p^{1}$ in 1948 and De Burgh v. De Burgh ${ }^{2}$ in 1952, were the most arresting. Their highly controversial interest was indicated by the division of the court itself. Both were four to three decisions. They are now so well settled into California's family law pattern as to be mere fragments of history for the overwhelming majority of the bench and bar. However, despite their loss of electrifying quality, Chief Justice Traynor's opinions in both these cases call for more than mere passing mention.

Perez v. Sharp, by holding Civil Code section $60^{3}$ unconstitutional, thereby established the legality of the miscegenetic marriage which, if celebrated in California, had been under statutory ban for a century. Applying at first only to inarriages between Negroes or inulattoes and white persons, the prohibitions of the original statute were twice expanded in this century. ${ }^{4}$

In the Perez opinion Chief Justice Traynor rested his conclusion that the miscegenetic prohibitions were unconstitutional mainly on the equal protection of laws clause in the United States Constitution. The arguments, long indulged in, that interracial marriage was socially dangerous because the non-Caucasians were "by native endowment inferior mentally, plrysically, morally and socially," were here advanced in the respondent's brief. They were examined in detail and adjudged without factual foundation. The intermarriage prohibitions were held arbitrary and discriminatory. The opinion was fortified by exhaustive research,

*A.B. 1913, J.D. 1915, Ph.D. 1921, University of California, Berkeley; LL.D. 1948, Mills College, LL.D., 1961, University of California, Berkeley; Professor of Law, Emeritus, University of California, Berkeley.

$\dagger$ Traynor, Comment on Courts and Lawmaking, in LEgat InsTrTUTIONS TODAX AND Tosrorrow 48, 56 (Paulsen ed. 1959).

132 Cal. 2d 711, 198 P.2d 17 (1948).

239 Cal. 2d 858, 250 P.2d 598 (1952).

3 Cal. Civ. Code $\S 60$ read at the time of the Perez case: "All marriages of white persons with negroes, Mongolians, members of the Malay race, or mulattoes are illegal and void." Cal. Stats. 1933, c. 104, p. 561. Repealed Cal. Stats. 1959, c. 146, p. 2043, § 1.

4 Cal. Civ. Code $\S 60$ was amended in 1905 to add the word "Mongolians," and in 1933 to add the words "members of the Malay race." Cal. Stats. 1905, c. 414, p. 554, § 2; Cal. Stats. 1933 , c. 104 , p. 561. 
was implemented by inexorable logic, and was illumined by occasional memorable sentences.

As to the bona fides of society in enacting the miscegenation ban, the shabby truth was pointed out.

The miscegenation statute ... condemns certain races as unfit to marry with Caucasians on the premise of a hypothetical racial disability, regardless of the physical qualifications of the individuals concerned. If this premise were carried to its logical conclusion, non-Caucasians who are now precluded from marrying Caucasians on physical grounds would also be precluded from marrying among themselves on the same grounds. The concern to prevent marriages in the first category and the indifference about marriages in the second reveal the spuriousness of the contention that intermarriage between Caucasians and nonCaucasians is socially dangerous on physical grounds. ${ }^{5}$

The opinion went on to consider the civil right at issue and the effect upon it of the inhibiting legislation.

The right to marry is as fundamental as the right ... to have offspring. Indeed, "We are dealing here with legislation which involves one of the basic civil rights of man." ... Since the essence of the right to marry is freedom to join in marriage with the person of one's choice, a segregation statute for marriage necessarily impairs the right to marry. ${ }^{\circ}$

And it reached its chmax in the statement:

[T] here is no redress for the serious restriction of the right of Negroes, mulattoes, Mongolians, and Malays to marry; certainly there is none in the corresponding restriction of the right of Caucasians to marry. A member of any of these races may find himself barred by law from marrying the person of his choice and that person to him may be irreplaceable. Human beings are bereft of worth and dignity by a doctrine that would make them as interchangeable as trains. ${ }^{7}$

Turning to the De Burgh v. De Burgh opinion in 1952, we find

6 Perez v. Sharp, 32 Cal. 2d 711, 723, 198 P.2d 17, 24 (1948).

${ }^{6} \mathrm{Id}$. at $715-17,198 \mathrm{P} .2 \mathrm{~d}$ at $19-21$.

${ }^{7} I d$. at 725,198 P.2d at 25 . It should be emphasized that Perez $v$. Sharp antedated by six years the celebrated United States Supreme Court's school integration opinion, Brown v. Board of Education, 347 U.S. 483 (1954), and apparently is the only instance of a state appellate court (through 1964, at least) holding a law forbidding miscegenetic marriage to be violative of the Federal Constitution. It should be added that Cahifornia's miscegenation enactment merited the slang description it has received on occasion, that it was a "carfare statute." In the early case of Pearson v. Pearson, 51 Cal. 120 (1875), as Chief Justice Traynor noted in the Perez opinion, a miscegenetic nuarriage celebrated in one of the 18 states which did not forbid it, was held valid here. Thus, it was established (by a decision never repudiated) that interracial couples who could afford a journey to such a state could there marry, and return here to live their lives with full marital status, while those without funds, however sincere their devotion to each other, were condernned to hive "in sin." Such a statute does not invite honor or respect.

839 Cal. 2d 858, 250 P.2d 598 (1952). 
Chief Justice Traynor reinterpreting the recrimination code sections, Civil Code sections 111.4 and 122. This reinterpretation resulted in a repudiation of the recrimination doctrine of the leading pre-code recrimination case, Conant $v$. Conant, ${ }^{8}$ the essence of which was that the right to divorce was automatically lost by a spouse otherwise entitled to it if his own conduct furnished a comparable cause for complaint. This doctrine was adjudged both uncalled for by the California divorce statutes as properly construed and also inapposite to sound public policy demands.

Supporting his interpretation listorically, by analysis of the Code Commissioners' notes, Chief Justice Traynor pointed out that neither Conant nor any other divorce case appeared among the precedents listed by the Commissioners as the basis of the recrimination statutes. In his words,

It is apparent from the decisions that were listed that the Legislature intended that divorce cases involving recrimination be governed by the same principles that apply generally throughout our jurisprudence. Although the plaintiff's fault has always been regarded as an important element in the decision of any case, our courts have traditionally refused to exalt that element above the public interest. . . . This respect for the public interest has formed the basis of a recognized exception to the equitable doctrine of unclean hands, with which the defense of recrimination has become increasingly identified since the enactment of the code. . . . It would be froward indeed for the court, when it is called upon to evaluate an alleged recriminatory defense, to ignore the growing awareness that a marriage in name only is not a marriage in any real sense... [E] quity does not deny relief on the ground of plaintiff's unclean hands when to do so would be harmful to the public interest. . . . Such a rule is even more appropriate in marital litigation, where the social consequences of the court's decree are of the utmost importance. ${ }^{10}$

In penetrating condemnation of the Conant rule, its principal vice was described as "its failure to recognize that the considerations of policy that prompt the state to consent to a divorce ... are often doubly present when both spouses lave been guilty. The disruption of family relationships, the clandestine associations with third parties, and the oppressive effect upon children and the community are intensified." The Justice concluded the core of his argument with the devastating judgment: "[I]t is a degradation of marriage and a frustration of its purposes when the courts use it as a device for punishment."11

910 Cal. 249 (1858).

$1039 \mathrm{Cal} .2 \mathrm{~d}$ at $866-69,250$ P.2d at 602-04.

11 Id. at 864,250 P.2d at 601 (Emphasis added.) In reversing and sending the $D e$ Burgh case back for retrial, Chief Justice Traynor gave full instructions for the implementation of the new rules in deciding the issues raised by a plea of recrimination. The court was directed to consider the prospect of reconciliation, the comparative fault of the 
It would be hard to overestimate how much this opinion did to restore integrity to the very process of law in divorce proceedings. For years, largely because of the recrimination sections, most divorce suits were collusive, uncontested suits agreed to by the parties and involving a "form" complaint of mental cruelty. On the record the plaintiff was an innocent victim grievously suffering. Corroboration as required by law ${ }^{12}$ was offered in "form" testimony presented by a member of the family or a close friend. Everyone present knew that practical perjury was being indulged in and the judge was powerless to prevent it. As many persons have their only contact with a courtroom in connection with such a divorce case, there was not only a personal loss to the dignity of the court in the proceeding, but a far greater loss to the general respect for law and its works.

These two outstanding opinions are but one part of the record. Probably no one judge of a court of last resort ever did more, from the standpoint of both procedural improvement and the promotion of human values, for the betterment and modernizing of the family law of his state, than Chief Justice Traynor.

The family law opimions with real significance which he has written over the years are so many, however, that a comprehensive account in a brief review such as this, inevitably would be pressed into hittle more than a histing of cases which would yield nothing of their flavor. Therefore it seemed best to forego a quantitative picture in the interest of concentrating on a few areas of special importance. The review that follows is concerned with: three notable opinions involving the well-being of children; three examples of "unfinished business," concurring opinions that still look to the future for final fruition; and, in conclusion, the long controversy over property settlement agreements, the last reviewed in somewhat unconventional terms.

THE WELL-BEING OF CHILDREN

The Child Born Out of Wedlock

In Rivieccio v. Bothan, ${ }^{13}$ by ingeniously combining Civil Code section $85^{14}$ with Civil Code section $215,{ }^{15}$ Chief Justice Traynor held a child

defendant and the plaintiff, and the effect of the marital strife upon the parties, their children, and the community. When it seemed advisable to grant a divorce to both parties an award of alimony to either party was within the court's discretion, but it was necessary to divide the community property evenly as an award of more than half was, by established rules, possible only when there was an "innocent party."

12 Car. Crv. Code $\$ 130$.

1327 Cal. 2d 621, 165 P.2d 677 (1946).

14 See text accompanying note 17 infra.

is Ibid. 
legitimate who, before this decision, would have retained the illegitimacy status into which he was born. This opinion also disposed of a reservation left in Estate of Shipp, ${ }^{16}$ which, while holding that a child born of a marriage invalid for procedural reasons was protected by section 85 , had queried whether section 85 applied to issue of a forbidden marriage such as an incestuous or deliberately bigamous marriage.

In Rivieccio the parents of a child born out of wedlock in Australia had married in reliance on a divorce decree which the father fraudulently obtained in California. This decree was later set aside. The case presented the problem whether the setting aside of the divorce decree reduced the child's status to that of illegitiniacy. Chief Justice Traynor held it did not.

The judgment annulling the divorce decree will not make defendant's child illegitimate. ... The child will not be deprived of the status of a legitimate child of the decedent. Under section 85 of the Civil Code "The issue of a marriage which is void ... is legitimate" while under section 215 of that code "A child born before wedlock becomes legitimate by the subsequent marriage of its parents." Such statutes "remove the stain and disabilities of bastardy" . . not only from children born after the void marriage of their parents or before their valid marriage, but also from children born, as defendant's child, before the invalid marriage of their parents. . . . The rights of defendant's child include any rights that a legitimate child has. . ...17

\section{The Legitimated Child's Inheritance Rights}

In his opinion in Estate of Garcia ${ }^{18}$ in 1949, Chief Justice Traynor achieved the long overdue resolution of a question affecting the inheritance rights of legitimated children. The question had arisen from the basic inconsistency between the language of Civil Code section 230 and that of Probate Code section 255. The former provided for "conduct legitimation" of the child born illegitimate and added that on compliance with its terms, "such child is thereupon deemed for all purposes legitimate from the time of its birth."19 The latter states that the illegitimate child "does not represent his father by inheriting any part of the estate of the father's kindred, either lineal or collateral, unless, before his death, his parents shall have intermarried, and his father, after sucli marriage, acknowledges him as his child, or adopts him into his family . . . ."20

16168 Cal. 640, 144 Pac. 143 (1914).

1727 Cal. $2 \mathrm{~d}$ at 626,165 P.2d at 680.

1834 Cal. 2d 419, 210 P.2d 841 (1949).

19 Cas. CIv. Code \& 230. (Emphasis added.) Legitimation under this section requires the father to (1) publicly acknowledge the child's paternity, (2) receive him into the family with the consent of his wife, if any, and (3) treat him as a legitimate child.

20 Cas. Prob. Code $\S 255$. This section provides first for the inheritance rights of a child born out of wedlock and then adds the provision about inheritance through the father which is quoted in the text. 
Chief Justice Traynor reviewed the history ${ }^{21}$ of the enactment of these sections, as well as the case law construing them. He then cut through the absurd situation resulting from previous interpretations to a conclusion consistent with California legislative history and with the current trend of California law, holding:

The cases involving the right of a person born illegitimate to inherit directly from his father have uniformly held that section 230 is not qualified by section $255 .$. . These words must have the same meaning with regard to inheritance through the father if their meaning has any consistency. . . . A child who is "deemed for all purposes legitimate" cannot be regarded as still illegitimate for some purposes. . . . The statutes are not in conflict when the words "illegitimate child" are interpreted as referring only to children born illegitimate who have not been legitimated under the provisions of the Civil Code. Although this interpretation renders some of the restrictive language of section 255 superfiuous, it is supported by the legislative history of the statutes. . . .22

The opinion concludes by specifically disapproving the supreme court's dictum to the contra in the opinion it rendered in denying a hearing in Wolf v. Gall. ${ }^{23}$

\section{The "Older" Relinquished Child}

Guardianship of Henwood ${ }^{24}$ involved half-orphan boys (aged five and eight) whose father, in a state of bitterness toward his deceased wife's mother (who wished to make a home for the children), had relinquished his sons to a licensed adoption agency. This the law permitted him to do. The maternal grandmother appealed from a refusal of the trial court to entertain her guardianship petition. The court stated that while it found lier a "fit person to have the children's custody," it was inhibited by law from passing on her petition as the boys were "relinquished" children.

Chief Justice Traynor, in deciding the appeal, was called on to settle a long-tinie controversy as to the propriety of appointing a guardian for a relinquished child. In so doing he gave the matter before him the special attention he always gives to implicit human considerations when resolving a procedural dispute which concerns family relationships. He first

21 Comment, 29 CAITF. L. REv. 185, 187-91 (1941) gives a full account of this history.

$2234 \mathrm{Cal}$. 2d at 421, 210 P.2d at 842. (Emphasis added.) It was made clear in Garcia that both legitimation through Civil Code $\S 230$ (which was involved in this case) and also legitimation through Civil Code $\S 215$ (spelled out in the Riveccio case, text accompanying note 17 supra) were included in the rules laid down in this case.

2332 Cal. App. 286, 296, 163 Pac. 346, 350 (1917).

2449 Cal. 2d 639, 320 P.2d 1 (1958). 
reviewed the statutory rules that created the conflict; the guardianship provisions authorizing "when necessary or convement" the appointment of a guardian ${ }^{25}$ who was to have custody and care of the child, and the pertinent provision in the adoption sections of the Civil Code which states that the placement agency should be "entitled to the custody and control of the [relinquished] child at all times until a petition for adoption has been granted."26 Pointing out that it was obviously impossible for the guardianship provisions and the adoption provisions "to control the custody of the same child at the same time," he added that the legislature had not expressly provided which should prevail. ${ }^{27}$

In his adjudication proper he determined as a preliminary inatter, that absent any such provision in the guardianship statutes, it could not be assumed that guardianship proceedings never could be entertained in reference to a relinquished child. Adding that adoption is ordinarily to be preferred to guardianship, he then held in reversing:

[W] conclude that the statutes . . . express by clear implication a legislative determination that the appointment of a guardian is not necessary or convenient while the adoption procedure is running its proper course. ... On the other hand, if the agency is shown to be unfit, the child's immediate welfare demands intervention, and if it is shown that adoption is improbable, continued waiting-room custody by the agency can no longer be justified as promotive of adoption, and the guardianship of a willing relative may well better serve the best interests of the child. ... [T] he trial court's ruling was based on the erroneous view that it had no jurisdiction in any case to appoint a guardian after a valid relinquishment had been made. Under these circumstances ... [appellant] should be afforded the opportunity to make a showing of necessity or convenience as herein defined. ${ }^{28}$

The reference to "waiting-room custody" of the child whose adoption is improbable manifested a sensitive appreciation of the situation of a group of children whose phight seldom receives attention-relinquished children who are past the age at which adoptive homes are hikely to be available. The strong urge to "belong" that most children feel empluasizes the importance of the place made in this Traynor opinion for consideration of any guardianship opportunity with a relative or a family friend that presents itself after a reasonable period of seeking a permanent home. The zealous guarding of exclusive jurisdiction over the relinquished older child which sometimes develops in agencies, no longer can claim legal justification.

25 Cat. Prob. Code § 1405.

26 Cax. Civ. COde \$ 224(n).

2749 Cal. 2 d at 643,320 P.2d at 3.

28 Id. at $645-46,320$ P.2d at 4-5. (Emphasis added.) 


\section{UNFINISHED BUSINESS}

Entry of Final Decree When Appeal is only from Collateral Provisions of Interlocutory Decree

In Harrold v. Harrold ${ }^{29}$ Chief Justice Traynor filed an important special concurring opinion ${ }^{30}$ which is far less widely understood than it should be. This case was directly concerned with the decision in Webster v. Webster, ${ }^{31}$ a divorce action in which an appeal had been taken only from the property division made by the court. Pending this appeal the trial court in that action had entered the final decree of divorce and had denied a motion for an order to vacate it. The supreme court reversed, deeming the entry "premature and improper" because of its literal reading of Civil Code section $132 .^{32}$

The opinion of the court in Harrold affirmed a judgment entering the final decree in a divorce proceeding, despite the fact that as a result of a previous appeal fron the division of the conınunity property in the interlocutory decree, there was still pending an accounting of the defendant's earnings being made to enable the trial court to implement the increased share which the appellate court had held the wife should receive.

In distinguishing Webster, which the court in Harrold professed not to be disturbing, it was stated by Justice Shenk (speaking for the court) that in the previous appeal of Harrold the appellate court, while reversing the property division in the interlocutory decree, had affirmed the interlocutory decree's "dissolution of the bonds of matriniony" and that this had become the law of the case. And it was held that there was, therefore, no legal impedinient to the entry of the final judguient during the period of the accounting which had been ordered in the new trial which followed the former appeal.

Chief Justice Traynor, while concurring with the holding that the final decree had been properly entered, did not agree with the majority opinion's analysis of the "law of the case." He pointed out that as the prior appeal had been taken only from the part of the interlocutory decree which divided the community property, the part dissolving the inarriage had not been before the district court of appeals, and the latter could not affirm that part of the decree. Noting that the present appeal was again from the part of the judgment dividing the colnmunity property, he

2943 Cal. 2d 77, 271 P.2d 489 (1954).

30 Id. at $86,271 \mathrm{P} .2 \mathrm{~d}$ at 495 .

31216 Cal. 485, 14 P.2d 522 (1932).

32 CAL. Crv. CODE $\$ 132$ reads in pertinent part: "If any appeal is taken from the interlocutory judgment or motion for a new trial made, final judgment shall not be entered until such motion or appeal has been finally disposed of ...." 
found the majority opimion, in approving the entry of a final decree, to be inconsistent with the reasoning in Webster. He concluded, however, that the interpretation given section 132 in Webster was erroneous, calling attention to the fact that this section is concerned solely with the dissolution of the marital relationship of the parties, and therefore should be interpreted to mean that "only when an appeal is taken from the provisions of the interlocutory decree dissolving the marriage is the entry of a final decree of divorce prohibited until that appeal is finally disposed of. . . ."33 He empliasized also that section 132 expressed a "legislative policy ... enabling [the parties] to remarry after the expiration of the one-year period,"34 a policy whose frustration by a "litigious spouse's repeated appeals from the provisions of the interlocutory decree dividing the community property"35 (exemplified by Harrold) was invited by the Webster rule, which was "out of harmony with the general rules giving finality to severable parts of judgments not appealed from or not subject to a motion for a new trial. ${ }^{\text {} 36}$ He maintained in conclusion:

The Webster case should be overruled ... and it should be held that a final decree of divorce can be entered at any time after the expiration of one year from the entry of the interlocutory decree, when, as here, there is no appeal from provisions of the interlocutory decree dissolving the marriage and the issues involved in an appeal from the provisions of the interlocutory decree dividing the property are severable from those involved in the dissolution of the marriage. ${ }^{37}$

It would seem that a rational appraisal of the opinion of the court in Harrold bears out Traynor's contention, and that to all intents and purposes the Harrold decision, while giving Webster lip service, implicitly overruled it. That the rejection of the Webster doctrine is sound and its express overruling desirable, for the reasons advanced in the Traynor concurring opinion, seems also a logical sequitur. This leaves the situation as somewhat "unfinished business" because lack of express overruling makes possible diverse interpretations of the law by the trial courts, a circumstance which is always regrettable and particularly so in the all too busy area of family law.

$3343 \mathrm{Cal} .2 \mathrm{~d}$ at 88, $271 \mathrm{P} .2 \mathrm{~d}$ at 496 (concurring opinion of Traynor, J.). (Emphasis added.)

34 Id. at 89,271 P.2d at 496.

35 Ibid.

$30 \mathrm{Ibid}$. He found the usual severability of the property provisions in the interlocutory decree well demonstrated by the frequent appeals taken only from the part of the decree which divided the community property and he rejected the Webster case rehance on the use of the word "any" as "not persuasive," because of the purpose of $\S 132$ and the rules governing partial appeals.

3743 Cal. 2d at 90, 271 P.2d at 497 (concurring opinion of Traynor, J.). 


\section{Entry of the Final Decree When Petitioner is in Contempt}

Hull v. Superior Court ${ }^{38}$ was a petition for a writ of mandate requiring the trial court to enter a final decree of divorce, motion for which had been denied because of defendant's alleged breach of an integrated property settlement agreement. Justice Peters, in his opinion for the court, held that even were defendant in contempt of court, ${ }^{30}$ the court, although permitted to do so, would not have been obliged to withhold the final decree for which he moved, and as defendant, at most, was merely in breach of his contract with his wife, he had an absolute right to its entry. The supreme court then ordered a writ of mandate to issue directing this entry.

Chief Justice Traynor was in full agreement with the mandate to the trial court. His reason for concurring specially had to do with certain statements in the court's opinion with reference to the effect of being in contempt on a party's absolute right to entry of a final decree of divorce. Tracing back to its origin the rule that the moving party's disregard of the court's orders justified denial of his motion for entry of a final decree, he stated that the rule had not been "formulated with the pohicy considerations appropriate to a divorce action in mind." ${ }^{40}$ Pointing out that the court's "power to withhold its processes, like its power to punish for contempt, rests on the necessity of upholding the court's dignity and enforcing its orders, ${ }^{\prime 41}$ he histed illustrative situations in which the court's processes had been appropriately witbheld. In conclusion, he reached his reason for writing this special concurring opinion:

When, however, there has been a final determination that the marriage should be dissolved, it is my opinion that the public interest in vindicating judicial dignity should yield to its interest in preserving the sanctity of marriage when the process sought to be withheld is a final decree of divorce, for "[i]t is a degradation of marriage and a frustration of its purposes when the courts use it as a device for punishment." 242

He therefore advocated (1) overruling the prior supreme court decision ${ }^{43}$ which had held to the contra, and disapproving the appellate cases which had followed suit, and (2) expressly holding that the trial court lacked discretion to withhold entry of the final decree of divorce solely because the moving party stands in disregard of its orders.

3854 Cal. 2d 139, 352 P.2d 161, 5 Cal. Rptr. 1 (1960).

30 Under Bradley v. Superior Court, 48 Cal. 2d 509, 310 P.2d 634 (1957) he could not be. See discussion in text accompanying note 101 infra.

4054 Cal. $2 d$ at $152-53,352$ P.2d at 169,5 Cal. Rptr. at 9.

$41 \mathrm{Id}$. at 153, 352 P.2d at 169, 5 Cal. Rptr. at 9.

42 Id. at 153, 352 P.2d at 169, 5 Cal. Rptr. at 10.

48 Weeks v. Superior Court, 187 Cal. 620, 203 Pac. 93 (1921). 
A consistent attitude toward the social policy concerning both divorce and marriage enunciated in De Burgh would seem to call for the implementing of this special concurring opinion by a formal opinion of the court. Pending litigation that furnishes such an opportunity, the matter perforce remains "unfinished business."

\section{The Mandatory Prospective Application Rule}

In Boyd v. Oser ${ }^{44}$ in a ten-line concurring opinion of outstanding importance, Chief Justice Traynor made a statement that stands as the lone protest from California's highest court membership against the wellknown "constitutional" doctrine that altering the marital property rules which existed at the tine of its acquisition constitutes the taking of properity from the owner spouse without due process of law, and that therefore such changes can be applied only "prospectively" to property thereafter acquired. This doctrine which made its initial appearance in the first Spreckels v. Spreckles ${ }^{45}$ in 1897 , as is well-known to California trained attorneys was not really at issue in the case; it rested on a concession of plaintiff's counsel that if the entire community property was vested in the husband it would be unconstitutional to change his control over the property, as established when he acquired it. As case law already liad solidified the view that the wife had no vested interest but only a mere "expectancy" in the community property, this concession disposed of the case. However, this "constitutional" doctrine has been followed and reiterated ever since.

In Boyd v. Oser, (a 1944 case) the Supreme Court extended the doctrine to cover rents, issues, and profits as well as the community property corpus in existence when a change was made. It held the Legislature to be without authority to grant the wife, who predeceased her liusband, the right to will away "her half" of such income as was acquired after the 1923 statute $^{48}$ (which gave the wife testamentary power over onehalf of the community property) whenever the property which produced the income had been accumulated prior to that date. ${ }^{47}$ This was the first

4423 Cal. 2d 613, 145 P.2d 312 (1944). This case was adjudicated nearly twenty years after the wife was given a vested one-half interest in the community property by Civil Code $\S 161(a)$.

$45116 \mathrm{Cal}$. 339, 48 Pac. 228 (1897). In this case the executor of the wife's estate sought to set aside the husband's gifts made after 1891 of community property which had been accumulated hefore the 1891 statute was passed forbidding such gifts without the wife's consent.

40 Cad. Prob. Code $\S 201$.

47 The rationale of the decision indicated that the wife's inability to include in her will pre-1923 community property was extended to the rents issues and profits of the rents issues and profits and to the latter's rents issues and profits, etc., etc., etc., apparently ad infinitum as long as any income was traceable back to the oxiginal pre-1923 corpus and until the marriage was dissolved by death or divorce. In Boyd some of the "income" at issue was clearly produced by income from pre-1923 community estate. 
time after the present Chief Justice became a member of the supreme court that a case involving the Spreckels rule of "mandatory prospective application" came before the court. With typical forthrightness he gave this rule the respect he thought it was entitled to while denying it a constitutional base. ${ }^{48}$

I concur in the judgment. The decisions that existing statutes changing the rights of husbands and wives in community property can have no retroactive application have become a rule of property in this state and should not now be overruled. It is my opinion, however, that the constitutional theory on which they are based is unsound. . . . That theory has not become a rule of property and should not invalidate future legislation in this field intended by the Legislature to operate retroactively. . . . ${ }^{48}$

In the twenty years since Boyd v. Oser the Legislature has passed a series of laws significantly affecting marital property rights, five, for example, in the $1950^{\prime} \mathrm{s}$ - two in $1951,^{50}$ one in $1955^{, 61}$ another in $1957,{ }^{52}$ and still another in $1959 . .^{53}$ One of these, ${ }^{54}$ was clearly prospective as the chaptered law, which added it to the code, so stated. There was nothing in the legislative history of another, ${ }^{65}$ which gave the wife management and control of her community property earnings which suggests any legislative desire to make the section operative as to earnings already accumulated. The remaiming three, however, are another matter. Although Civil Code section 169.1 speaks in terms of "each spouse," it, as well as section 169.2 and section 175's amendment, were 'husbands' relief measures" directed at only one objective, to put the separated husband's relation to his earnings on at least a near parity with that which his wife had enjoyed since $1872 . .^{56}$ It is not credible that the Legislature's intent fell short of application, as far as legally possible, of the long-delayed remedial measures to all property satisfying the enactments' specifications.

Nothing in the language of the statutes suggests a "prospective appli-

48 For a discussion of pertinent decisions of the United States Supreme Court, see Armstrong, "Prospective" Application of Changes in Community Property Control-Rule of Property or Constitutional Necessity, 33 Caurr. L. REv. 476-505 (1945); Conment, 27 CaLIF. L. Rev. 49 (1938).

4923 Cal. $2 \mathrm{~d}$ at 623,145 P.2d at 318. (Emphasis added.)

50 CAL. Crv. Code $\$ \S 169.1,171$ (c).

51 Amendment to CaL. Crv. Code \& 175.

52 Cat. Crv. CODE $\$ 163.5$ providing that damages recovered for personal injuries are the separate estate of the injured spouse.

53 CAL. CIV. Code § 169.2.

54 CaI. Crv. Code $\$ 163.5$.

55 CaI. Civ. Code $\$ 171$ (c).

$56 \mathrm{CAL}$. CIv. Code $\$ 169$ has provided since the adoption of the codes that when a wife lives separate and apart from her husband her earnings and accumulations are her separate property. 
cation" intent on the part of the Legislature. All use the word "are" instead of "shall be." Ap7 Apparently only two of these three enactments have received appellate review. The second district's decision in Jacquemart v. Jacquemart ${ }^{58}$ construed Civil Code section 169.1. It rejected the husband's contention that his accumulation from earnings between 1942, when a separate maintenance decree had been entered in favor of his wife, and 1951, when section 169.1 became effective, should be deemed his separate property. The court conceded that "This would seem to be a fair and equitable view of the law of community property, at least as it should have been. And fairness and equity would seem to have been the motivating purpose of the Legislature in enacting the new code section. ${ }^{269}$ It then referred to constitutional, statutory and case law bearing on the question and refused to accept appellant's argument because "The general rule is that ... . legislation changing the respective rights of the husband and wife in community property will not be given retroactive effect. ${ }^{200}$

The family still is the basic unit of our society however it may at times be abused, and contemporary constitutional theories of due process do not support the theory that the legislature is not free to try to improve its stability by sucl property clranges as seem likely to do so. Nor do our higl court's opinions suggest it is not constitutionally authorized to establish more equitable adjustment of property relations between the spouses (as to existing marital property) when the family is disrupted, if existing rules rooted in the past prove unfair and undesirable under current social

67 Thus, Civil Code $\$ 169.1$ (enacted in 1951) states that the earnings or accumulations (of either spouse) after a separate maintenance decree "are" (not shall be) the separate property of the party acquiring such earnings or accumulations. Similarly, the 1955 aunendment of Civil Code $\S 175$ states that the husband's earmings when his wife unjustifiably abandons him and until she offers to return "are" his separate property, and Civil Code $\S 169.2$ (added in 1959) states that after an interlocutory decree of divorce (and while the parties are living separate and apart) the earnings and accumulations of the husband "are" his separate property.

58125 Cal. App. 2d 122, 269 P.2d 951 (1954).

69 Id. at 124,269 P.2d at 952 .

60 Civil Code $\S 175$ was reviewed by the first district in Ottinger v. Ottinger, 141 Cal. App. 2d 220, 296 P.2d 347 (1956). There the husband had obtained a default judgment of divorce in Nevada in 1953, two years before the amendment of Civil Code $\$ 175$. The propriety of this Nevada decree was challenged later in California but was held valid. The California court then held that on entry of the Nevada judgment the parties became tenants in common of the community property, which included the husband's earnings (and accumulations therefrom) up to that date. The husband appealed contending that a deserting wife was not entitled to share in her husband's earnings during their separation. The appellate court rejected this contention, saying, in affirming that while the legislature had changed the former rule in 1955 , the section obviously was not retroactive as the rights of the wife were vested and "such vested rights could not, constitutionally, be divested by the passage of section 175." Id. at 225, 296 P.2d at 351 . 
conditions. ${ }^{61}$ A doctrine that freezes for all time ownership and controls of marital property as of the date when it or the property to which it can be traced was acquired, should not be allowed indefinitely to hide behind assumed constitutional necessity. Nothing but an affirmation by the supreme court as a whole of the verity of Chief Justice Traynor's concurring opinion in Boyd v. Oser which disputed the constitutional view of the Spreckels case as erroneous will make it possible at the discretion of the legislature, for marital property changes to be effective as to existing property and as to future rents, issues and profits derived from existing property, as well as to future earnings of the spouses.

This would seem to be "unfinished business" of primary importance, and it may be hoped that such a case as Jacquemart in which a hearing by the supreme court was not requested will, before long, present the supreme court with an opportunity to reexamine the Spreckels doctrine.

\section{THE PROPERTY SETTLEMENT AGREEMENT CONTROVERSY}

In Adams v. Adams, ${ }^{62}$ Chief Justice Traynor wrote for the court the first of a series of opinions concerning property settlement agreements. These opinions were, and still are, of obvious interest to the majority of practitioners who in this era of prevalent divorce and separation are frequently called on to negotiate the property division and support provisions of an agreement to be presented to a court for incorporation in a decree. Special attention to these decisions seemed called for.

The Adams case involved an agreement in which the wife waived all support after eighteen months in return for the husband's promise to give her the major part of the community property. Each party released the other froin all obligations, including claims for marital support except as provided in the agreement and specified it was "understood that this instrunient is intended to settle the rights of the parties hereto in all respects." "33 At a later divorce trial (an uncontested suit) the trial judge over the protest of the wife refused to approve the agreement. ${ }^{64} \mathrm{He}$ gave the parties a choice between stipulating to fifty dollars a month for support of the wife as well as the child, as an amendment to the contract, or,

61 Indeed a strong case has been made, based on careful analysis of United States Supreme Court decisions, for the conclusion that the legislature is free of any substantive due process restraint, in legislating changes that are economic in character. See McClosky, Economic Due Process and the Supreme Court: An Exhumation and Rebutrial; THE SUPREME Coúrt REvIEw, 1962, 34 (Kurland ed. 1962). See also Hochman, The Supreme Court and the Constitutionality of Retroactive Legislation, 73 HaRv. L. REv. 692 (1960), especially the conclusion at 726-27. See Note 48 supra.

6229 Cal. 2d 621, 177 P.2d 265 (1947).

63 Id. at 622,177 P.2d at 266.

64 She honorably maintained that the husband had carried out his part of the agreement and that she was satisfied with the contract as made. 
if the husband refused to so stipulate, an amendment to the wife's complaint requesting such a change in the prayer. The husband did refuse to stipulate and in due course the wife amended her prayer as directed. The divorce court then approved the property settlement agreement except for the eighteen-month limitation on the support payments which it deleted and, in addition, it changed the award of fifty dollars monthly for child support to "alimony and child support" in accordance with the wife's amended prayer. The husband appealed.

Before discussing the case before him, and obviously for the instruction of both the trial courts and the bar, Chief Justice Traynor outlined the possible contents of various types of property settlement agreements and their significance. He pointed out first, citing previous supreme court decisions, that the general social policy was to favor such agreements. He indicated the limits on the court's discretion when its approval of a property settlement agreement was requested, stating "When the parties have finally agreed upon the division of their property, the courts are loath to disturb their agreement except for equitable considerations. A property settlement agreement, therefore, that is not tainted by fraud or compulsion or is not in violation of the confidential relationship of the parties is valid and binding on the court." ${ }^{65} \mathrm{He}$ then analyzed the three most usual methods of handling support and maintenance provisions in property settlement agreements. Commenting that these provisions caused "the most difficult problems" when agreements were presented to the divorce court, he stated that the first method was to include a completely separable support and maintenance clause " $\mathrm{m}$ the nature of alimony" unrelated to the property division provisions. Such a clause, he pointed out, if incorporated in the divorce decree, was modifiable in accord with the court's power over alimony generally. ${ }^{66}$ Then, inserting an additional gem of information for the practitioner, he also stressed the fact that a contract might provide solely for support and maintenance and, at the option of the parties, not be presented to the court at all (and thus not be modifiable) without sacrificing its enforceability as a contract as long as it was equitable.

The second type of support and inaintenance provision, Traynor explained, actually was not in the nature of alimony but comprised pure property installment payments ${ }^{67}$ which were given to the wife in lieu of the lump sum due her as her community property share. As property division they were not subject to modification, and the court might also properly award alimony.

$65 I d$, at 624,177 P.2d at 267.

66 CaI. Crv. Code $\S 139$.

67 He cautioned that calling these pure property payments "alimony" or "support and maintenance" payments was bad practice and led to later litigation. 
He described the third type of support and maintenance provision as one which was an inseparable part of an integrated bargain (exemplified by the case before him) in which the amount of alimony to the wife was made dependent upon the share of the community property she would receive, and all payments except as provided by the agreement were waived. The court, he added, in reversing, could refuse to approve or incorporate any agreement it deemed inequitable but its discretion did not include modification of an integrated agreement by ordering additional support and maintenance contrary to its terms, as this would effectively destroy the bargain made by the parties.

All the Justices signed this opimion.

Not for seven years did Chief Justice Traynor again review a property settlement agreement which contained a property division clause, a waiver clause, and a support and maintenance clause the character of which was in dispute. Then Dexter v. Dexter, ${ }^{68}$ Fox v. Fox, ${ }^{60}$ and Flynn v. Flynn ${ }^{70}$ came to his hand. The main contribution of his opimions in the first two of these cases lay in his exposition of the stigmata of an integrated property settlement agreement and his analysis of the nature of support and maintenance provided in such a contract. In Dexter, on the ground of lack of jurisdiction to modify, the trial court had refused to increase the support provision included in a property settlement agreement which had been incorporated and merged in a divorce decree some eight years before. Plaintiff appealed, relying on Adams. She alleged that the community property had been evenly divided and contended that waiver of support other than as provided in the contract was valid only when given in exchange for a greater share of the community property than she would otherwise have been entilted to receive. This argument Traynor found not tenable. In affirming, he pointed out that the rationale of the Adams decision apphied equally to other types ${ }^{71}$ of integrated bargains. Accordingly, he concluded that an even division of the community property had no bearing on the validity of the provision of the agreement whereby both parties waived all rights to support and maintenance other than as provided therein.

He also analyzed the nature of the support payments provided for in an integrated bargain:

6842 Cal. 2d 36, 265 P.2d 873 (1954).

6942 Cal. 2d 49, 265 P.2d 881 (1954).

7042 Cal. 2d 55, 265 P.2d 865 (1954).

$71 \mathrm{He}$ gave as examples (1) the possibility that the spouses might be in disagrecment as to the marital property character of some of their holdings and prefer not to risk court determination of their dispute, or (2) the plaintiff might prefer to accept an equal division of the community property (when her ground of divorce entitled her to more than one-half) in exchange for support payments that could not be reduced. 
When as in this case ... the parties have made the provision for support and maintenance an integral part of their property settlement agreement, the monthly payments will ordinarily have a dual character. To the extent that they are designed to discharge the obligation of support and maintenance they will ordinarily reflect the characteristics of that obligation and thus have indicia of ahmony. ... On the other hand, to the extent that they represent a division of the community property itself, or constitute an inseparable part of the consideration for the property settlement, they are not abmony, and accordingly cannot be modified without changing the terms of the property settlement agreement of the parties. ${ }^{72}$

In Fox v. Fox, ${ }^{73}$ handed down on the same days as Dexter, Chief Justice Traynor again was confronted by a property settlement agreement which, like the contract in Dexter, had been incorporated in a divorce decree and ordered to be performed. Five years later on the former wife's motion the trial court had increased the payments for her support and defendant appealed.

Chief Justice Traynor reversed, as on review of the terms of the agreement he found it to be an integrated contract. To the respondent's contention that the trial court by increasing the payment had impliedly found them to be alimony and the further contention that this conclusion was supported by the labeling of the payments as alimony, he answered: "In the absence of conflicting extrinsic evidence, the interpretation placed upon the agreement by the trial court is not binding on this court on appeal. ... The labels adopted by the parties are not conclusive, since the agreement must be considered as a whole." ${ }^{4}$ Justice Carter dissented in both cases.

At the same time that he wrote his Dexter and Fox opinions Chief Justice Traynor resolved for the court a controversy involving the permissible methods of incorporating a property settlement agreement into a decree and merging it therewith. In Flynn v. Flynn the divorce court, in accord with the express consent of the parties, had purportedly incorporated a property settlement agreement in the interlocutory decree by the statement that the agreement "received in evidence herein, is hereby ratified, approved and confirmed and ... specifically incorporated herein and made a part of this decree, and defendant is hereby ordered to make all of the payments provided therein to be paid by him. . . '"75

Later, defendant petitioned for an order reducing these payments. The order was denied on the ground of the lack of jurisdiction because the

7242 Cal. 2d at $41-42,265$ P.2d at 876-77. (Emphasis added.)

7342 Cal. 2d 49, 265 P.2d 881 (1954).

74 Id. at $52-53,265$ P.2d at 883 .

7642 Cal. 2d 55, 57, 265 P.2d 865 (1954). (Emphasis added.) 
incorporation was by reference only and so did not bring about a merger of the agreement into the decree. Chief Justice Traynor affirmed the divorce court's order denying the defendant's petition, but did so on the sole ground that the terms of the agreement itself expressly disentitled him to have his obhigations lessened, except as his earnings fell below a stipulated amount, a circumstance that he had not established at the trial.

As to the controverted question of merger, Chief Justice Traynor, with his customary consideration for the need of the trial bench and the bar for summarized information, laid down the general ground rules for incorporation and merger:

[I] $t$ is first necessary to determine whether the parties and the court intended a merger. If the agreement is expressly set out in the decree, and the court orders that it be performed, it is clear that a merger is intended.... Whether or not a merger is intended, the agreement may be incorporated into the decree. ... If a merger is not intended, the purpose of incorporation will be only to identify the agreement so as to render its validity res judicata in any subsequent action based upon it. . . . Once it is determined that a merger was intended, it is necessary to decide whether the decree has the requisite formalities to permit its enforcement in place of the agreement it was intended to supersede. ${ }^{76}$

He then considered plaintiff's contention that a document could not be effectively incorporated by reference unless it was part of the permanent records of the court, because an exhibit could be withdrawn or destroyed and interested parties could not by searching the records of the court construct a complete picture of the rights and obligations of the parties.

Reserving the questions of whether incorporation by reference to an exhibit would be deemed adequate as a basis for contempt proceedings or when the rights of third parties were involved, Chief Justice Traynor held such incorporation adequate for purposes of hitigation between the spouses who had entered into the agreement and had requested its inerger. ${ }^{77} \mathrm{He}$ then affirmed the order.

In Finnegan v. Finnegan, ${ }^{78}$ decided shortly after Dexter, Fox and Flynn, Chief Justice Traynor spelled out an aspect of the integrated property settlement institution not yet reviewed by the court and in need

${ }^{76}$ Id. at $58-59,265$ P.2d at 866-67.

77. In justification of incorporation (and merger) by reference to an exhibit "to give effect to the clearly expressed intent of the decrees" he pointed out that this presented no greater difficulty than the taking of extrinsic evidence to determine the intended character of a property settlement agreement when this could not be accurately determined from the permanent records of the court.

7842 Cal. 2d 762, 269 P.2d 873 (1954). 
of elucidation. The case was that of a married couple, living separately, with their rights and obligations settled by a separate maintenance judgment based on a property settlement agreement which had been approved and incorporated, with performance expressly ordered by the court. The wife's petition later for an increase in the payments for her maintenance was demed. She appealed.

Chief Justice Traynor said im affirming:

[A]s in the Dexter and Fox cases, the parties made the provisions for support and maintenance an integral part of their property settlement agreement. . . . Plaintiff has accepted the benefits of the agreement, and defendant has at all times performed his obligations thereunder. The situation has not been altered by an unaccepted offer of reconciliation ... or by a reconciliation ... and neither of the parties has given the other grounds for abrogating the agreement. . . U Under these circumstances there is no reasonable basis for holding that their agreement is not binding upon them and the court. Accordingly, the court cannot modify the payments . . . ${ }^{79}$

The effect upon the situation of either a conciliation offer or an actual reconciliation obviously was reserved but there was left the undoubted implication that either might terminate or otherwise affect the contract's effective control.

Prompted by Justice Carter's insistence in his dissents that both the bar and the trial court judiciary had been put into a state of "confusion" by the Dexter and Fox decisions as to the exact nature of an integrated property settlement agreement, Chief Justice Traynor found it necessary in each of the subsequent integrated property settlement cases to review the analysis he had made in previous loldings, and to point out why the case being decided fell into the "integrated bargain" pattern that the earlier decisions had delineated. Commencing with Messenger v. Messenger, ${ }^{80}$ after such a review, he additionally described the terms of an agreement which, as a matter of law, was an integrated property settlement agreement.

When as in this case the parties have clearly expressed their "purpose of fixing and adjusting their personal and property rights," lave provided that the provision for alimony is "for and in consideration of the permanent and lasting division and settlement of all their property rights of every kind and nature," and the wife has waived "all right to future maintenance and support . . except as herein otherwise expressly provided," the conclusion is inescapable that they have made the provisions for the support and maintenance an integral and insep-

79 Id. at 765-66, 269 P.2d at 874-75. Note that Cardinale v. Cardinale, 8 Cal. 2d 762, 68 P.2d 351 (1936), referred to in this case was overruled on another point in Hudison v. Hudson, 52 Cal. 2d 735, 743, 344 P.2d 295, 299 (1959).

8046 Cal. 2d 619, 297 P.2d 988 (1956). 
arable part of their property settlement agreement. With such conclusive evidence of integration, the provisions for support and maintenance or alimony would be subject to modification only if the parties expressly so provided. . $^{81}$

This statement he reiterated by quoting verbatim from Messenger in his later opinions for the court in Anderson v. Mart ${ }^{82}$ and in Herda $v$. Herda. ${ }^{83} \mathrm{He}$ repeated it in paraphrased form in the still later Plumer v. Plumer $^{84}$ case. Surely by the time that this had been spelled out four times, at least the pattern of the inescapably integrated property settlement agreement could no longer have been obscure or confusing to either bench or bar.

\section{The Dissents}

Meantime, as already stated, there had been a dissenter in Dexter and Fox-Justice Carter. He had not only maintained that these decisions caused "confusion," but he also contended that there was only one way to eliminate this confusion, namely, to follow the "proper rule." This, he said, was the "rule" that both an exclusively support contract and a severable alimony clause in an agreement between the spouses, even if

$81 \mathrm{Id}$. at $628,297 \mathrm{P} .2 \mathrm{~d}$ at 992 . (Emphasis added.) This was especially informative to the trial bench as it made clear that a contrary determination (in the face of such terms in a contract), even when conflicting extrinsic evidence had been considered at the trial, would be overruled on appeal, on point of law, as in any other case when a trial court reached a conclusion contrary to governing rules of law.

8247 Cal. 2d 274, 279, 303 P.2d 539, 542 (1956).

8348 Cal. 2d 228, 232, 308 P.2d 705, 710 (1957).

8448 Cal. 2d 820, 825, 313 P.2d 549, 552 (1957). All of the cases from Dexter through Plumer involved integrated agreements whose classification as such was in dispute. The actual holdings also concerned: In Messenger v. Messenger, 46 Cal. 2d 619, 297 P.2d 988 (1956), the discretionary nature of the execution remedy (under the 1951 amendment to Civil Code \$ 139); in Anderson v. Mart, 47 Cal. 2d 274, 303 P.2d 539 (1956), the effect of agreeing to a composite sum for support of the wife and child; in Herda v. Herda, 48 Cal. 2d 228, 308 P.2d 705 (1957), the implied intention of the parties that payments should cease on the wife's remarriage; in Plumer v. Plumer, 48 Cal. 2d 820, 313 P.2d 549 (1957), the meaning of the contract's clause providing for possible future changes in the payments. The construction of the 1951 amendment to Civil Code $\$ 139$ in Messenger, referred to above, making execution to enforce support payments which were subject to Civil Code \$ 139 diseretionary was not only contrary to the most defensible reading of the section but has also proved to be most unfortunate in the light of the Bradley v. Superior Court case's later removal of the contempt remedy for such enforcement. (See text accompanying note 101 infra for discussion of Brodley.) However, the 1963 case of Di Marco v. Di Marco, $60 \mathrm{Cal} .2 \mathrm{~d} \mathrm{387,} 385$ P.2d 2, 33 Cal. Rptr. 610 (1963) in reversing the trial court's holding that had demed execution, referred only to Di Corpo v. Di Corpo, 33 Cal. 2d 195, 200 P.2d 529 (1948), (antedating the 1951 change) and held that execution under Code of Civil Procedure $\$ 681$ was available to the plaintiff automatically as a right as to amounts that had become due in the previous ten years and that hardship to the defendant in result of such execution was immaterial. No reference whatever was made to Civil Code § 139, which suggests a sub silentio overruling of the Messenger case interpretation of Civil Code $\S 139$. 
incorporated and merged in a divorce decree, having once been found by the court to be fair and equitable, should never be subject to modification except by the subsequent agreement of the parties.

This contention was in direct contradiction of his own opinion (for the court) in Hough v. Hough. ${ }^{85}$ It also, of course, behed his signature of the Adams opinion, and most important, it violated the rule laid down by the legislature in Civil Code section 139 as to the court's continuing power to modify its alimony decrees.

Howso be it, these Carter dissents turned out to be the beginning of a veritable crusade. In every one of the seven subsequent property settlement cases imvolving the existence or non-existence of an integrated bargain which reached the Supreme Court while he was still on the bench, he dissented. ${ }^{86}$ Each time he made the same contention that "confusion" was caused by the opinion of the court and only his "proper rule" would dispel it."

In Flynn v. Flynn, ${ }^{88}$ already mentioned as a contemporary of Fox and Dexter, Justice Carter found a co-dissenter. Justice Schauer, who had made no objections to the Dexter and Fox opinions, vehemently disagreed with the basic doctrine of Flynn v. Flynn that incorporation (and merger) of an agreement could be achieved by reference to an exhibit. He maintained that only what went into the judgment book (which, of course an exhibit did not) was "incorporated in a decree" and that incorporation by reference to an exhibit was therefore a legal impossibility. Apparently, Justice Schauer then decided to pool grievances with Justice Carter. He subscribed to Carter's "proper rule" cally denounced ${ }^{00}$ "incorporation by reference." Justice Carter continued to do the latter in a number of subsequent cases, although devoting

8526 Cal. $2 d 605,615,160$ P.2d 15, 20 (1945). In this case the court held that the divorce court had the power "on an application for modification [of the support clause in a property settlement agreement] ... to decide ... whether the decree is based upon a property settlement agreement, and is not subject to modification, or is based upon alimony or support allowance covenants, and is subject to modification." (Emphasis added.)

86 When he was obliged to concur in a judgment, because for one reason or another the contract before the court was interpreted as not permitting a change in the support provisions, he dissented to the grounds of the majority opinion or to the court's reasoning and reiterated all his former dissents: e.g., in Finnegan v. Finnegan, 42 Cal. 2d 762, 269 P.2d 873 (1954), and Messenger v. Messenger, 46 Cal. 2d 619, 297 P.2d 988 (1956).

87 Dexter v. Dexter, 42 Cal. 2d 36, 46, 265 P.2d 873, 879 (1954); Fox v. Fox, 42 Cal. 2d 49, 54, 265 P.2d 881, 884 (1954); Flynn v. Flynn, 42 Cal. 2d 55, 67, 265 P.2d 865, 871-72. (1954); Messenger v. Messenger, 46 Cal. 2d 619, 630, 632, 297 P.2d 988, 994, 995 (1956); Herda v. Herda, 48 Cal. 2d 228, 240, 308 P.2d 705, 712 (1957); Plumer v. Plumer, 48 Cal. 2d 820, 828-31, 313 P.2d 549, 555-57 (1957).

8842 Cal. 2d 55, 265 P.2d 865 (1954).

89 Id. at 62,265 P.2d at 868 .

90 Id. at 63-67, 265 P.2d at 869-71. See also Foust v. Foust, 47 Cal. 2d 121, 126-28, 302 P.2d 11, 15-16 (1956). 
the better part of his dissents to his "proper rule" and also to bitter complaint that failure of the court to accept this rule constituted failure to give a contract between the spouses the same dignity and standing as was accorded to contracts between persons not so related. ${ }^{01}$ This complaint was so unfounded as to be practical nonsense. As Chief Justice Traynor had carefully pointed out in his foundation case of this series, Adams v. Adams, ${ }^{92}$ contracts between the spouses exclusively for support, and contracts for both support and property division provided in severable clauses, if equitable, are valid and enforceable (and thus unmodifiable) when they are not presented to the divorce court for merger in the court's decree but remain "out of court" contracts. Thus, they are on a parity with any other type of contract, such as one for the purchase of cement or the building of a house. What distinguishes these "other types of contract" from the support agreement by the spouses (via a severable clause or an exclusively support contract) which by their voluntary act is ploughed into and merged in a divorce court's decree and thus loses its independent status as a contract, is that the "other types of contract" he talked about do not and cannot get merged in court decrees and lose their identity. ${ }^{93}$ When a severable provision for pure alinony is merged in a divorce court's decree it inevitably becomes subject to the court's power of modification granted by Civil Code section 139.

Foust v. Foust, 94 another "incorporation by reference" case, in which Justice Spence wrote the court's very sensible opinion, is here referred to because it produced a third dissenter in the person of Justice Shenk. While the latter had accepted "incorporation and merger by reference" in Flynn, in which the trial court had expressly ordered performance of the agreement, he refused to dispense with an express order and accept an implied order as was done in the Foust decision. Justice Shenk apparently regarded such procedure as disorderly and inadequate for producing a merger, even for execution purposes.

91 Dexter v. Dexter, 42 Cal. 2d 36, 44, 265 P.2d 873, 878 (1954); Messenger v. Messenger, 46 Cal. 2d 619, 630, 297 P.2d 988, 994 (1956); Plumer v. Plumer, 48 Cal. 2d 820, 826,313 P.2d 549,554 (1957).

9229 Cal. 2d 621, 624, 177 P.2d 265, 267 (1947).

93 Confusion was undoubtedly promoted by this "complaint" which while unfounded in legal analysis was in the sound tradition of the less responsible part of the advertising industry, which more than once has proved that even a preposterous claim if repeated often enough can make a place for itself.

9447 Cal. 2d 121, 302 P.2d 11 (1956). Conceding it was, of course, better practico to have the agreement set forth in the decree in haec verba-or attached to the decree, since only execution (and not contempt) was at issue, he felt that even the absence of an express order of performance did not prevent merger for that purpose as "to hold otherwise would require the parties. to engage in needless further hitigation-to merge the agreement into another decreo. ..." Id. at 125, 302 P.2d at 14 . 
In the next three cases $^{95}$ all three Justices (Carter, Schauer and Shenk) continued to be dissenters, objecting either to the holdings proper or to the grounds on which they rested. In the last of the series, Plumer v. Plumer, ${ }^{96}$ however, Justices Schauer and Shenk, while concurring only "in the judgment" did so without opinion. Thus, Justice Carter, dissenting as usual, found himself, as when he commenced his crusade in the Dexter and Fox cases, alone. Without cohorts, he reiterated the strongest edition of his usual dissent, stating flatly that, in his opinion, the court was without the power to modify any support agreement of the spouses, merged or not in a decree. ${ }^{97}$ And then, surprisingly enough, he added his own formal disapproval of his own holding in Hough $v$. Hough. ${ }^{98}$

\section{The Bradley Case}

In the twelve years and ten property settlement agreement cases from Hough v. Hough $h^{99}$ through Plumer v. Plumer ${ }^{100}$ somehow the foundation was laid for the case of Bradley v. Superior Court. ${ }^{101}$ Bradley was a most unfortunate, as well as unheralded, decision in which the supreme court, without admitting it, overruled the decision and reasoning of Miller $v$. Superior Court, ${ }^{102}$ handed down by the court twenty years earlier. Speakmg for five of his colleagues Justice Schauer cited the Miller case and quoted (out of context) two selected sentences ${ }^{103}$ as authority for the court's own erroneous conclusion! Only the Traynor dissent in Bradley v. Superior Court saved the record from utter blackness.

Bradley, briefly stated, held that the contempt process could not be used to enforce the support clauses in an integrated incorporated (and merged) agreement, payment having been expressly ordered by the court; this on the ground that such enforcenient would involve imprisonment for debt and was therefore prohibited by the constitution. The conclusion of the court was supported by discussion not always easy

05 Messenger v. Messenger, 46 Cal. 2d 619, 297 P.2d 988 (1956), Anderson v. Mart, 47 Cal. 2d 274, 303 P.2d 539 (1956), Herda v. Herda, 48 Cal. 2d 228, 308 P.2d 705 (1957).

9648 Cal. 2d 820, 313 P.2d 549 (1957).

97 Id. at 828,313 P.2d at 554 .

9826 Cal. 2d 605, 160 P.2d 15 (1945). Justice Carter, at this point disapproving Justice Carter, inevitably suggests that some of his colleagues may more than once, during these property settlement cases, have called to his attention the incompatibility of his "proper rule" with his own holding in Hough."

99 26 Cal. $2 \mathrm{~d} 605,160$ P.2d 15 (1945).

10048 Cal. 2d 820, 313 P.2d 549 (1957).

10148 Cal. $2 \mathrm{~d}$ 509, 310 P.2d 634 (1957).

1029 Cal. 2d 733, 72 P.2d 868 (1937).

10348 Cal. 2d 509, 520, 310 P.2d 634, 641 (1957) quoting, with "selectivity" from Miller v. Superior Court 9 Cal. 2d 733, 739, 72 P.2d 868, 872 (1937). 
to follow. ${ }^{104}$ It was summarized, however, in the concluding paragraphs of the decision:

[T]he better view is that payments provided in a property settlement agreement which are found to constitute an adjustment of property interests, rather than a severable provision for alimony, should be held to fall within the constitutional proscription against imprisonment for debt. That is, if the obligation sought to be enforced is contractual and negotiated, as distinguished from marital and imposed by law, even though the contract relates to marriage obligations, the remedy must be appropriate to the right asserted. Payments which fall into the category of law-imposed alimony or separate maintenance are based upon the statutory obligation of marital support, may be modified by the court upon a proper showing, ordinarily terminate with the death of either party, and may properly be held not to constitute a "debt" within the meaning of the constitutional provision. ${ }^{105}$

104 See, e.g., 48 Cal. 2d 520-21, 310 P.2d at 641, especially the last two sentences on p. 520 and the first two on p. 521 which seem both obscure and perhaps contradictory. What did the court mean when it said, "there may be situations in which the fact that a party has agreed to pay some fixed or ascertainable amount as alimony does not change or control the character of the ohligation sought to he enforced by the othcr?" (What situations?) And what did the court add by stating (what every lawyer knows) that "in the absence of a waiver by the contracting spouses . . . of reciprocal rights to support other than as provided in the agreement, either party may properly seck to enforce .. . the obligations imposed by law as incidents of the marriage"? Did the court inean readers to deduce that agreed support plus a waiver clause, added up to the production of a mere debt, constitutionally beyond the limits of enforcement by contempt proceedings? Or shall we conclude, echoing in both rhythm and content, Alice in the famous Wonderland, "It serves us naught, To pick and choose, They only said it to confuse!"

105 Bradley v. Superior Court, 48 Cal. 2d 509, 522, 310 P.2d 634, 642 (1957). (Emphasis added.) Cf. note 104 supra. For adverse criticism of Bradley, see 10 Stan. L. REv. 321 (1958), 45 CAIIF. L. REv. 782 (1957). The reaction of practitioners, as evidenced by the work of several committees of the State Bar, was that of dismay coupled with determination to find some way to regain the advantages previously enjoyed with the integrated agreement, i.e., immutability of the payments plus the right to enforce them through contempt proceedings. The first legislative response to the situation was an amendment in 1959 to Civil Code $\$ 139$, which gave the court the power to "modify or revoke at any time" "any order for support of children based on a provision for such support in an integrated property settlement agreement. . . "This was obviously designed (and effectively so, in this writer's opinion) to make it possible to enforce such support provisions by contempt proceedings. It also, of course, in practical effect removed child support from the scope of merged integrated contracts. This change was followed in 1961 by two other amendments of $\S 139$ which gave the court similar power to modify or revoke orders for the support of the other spouse based upon provision for such support in an integrated merged agreement, except when there were no minor children of the parties. Thus, real integrated agreements (i.e., modifiable only with the consent of the parties) if merged in a court decree, were possible between the spouses only under the stipulated condition. Both of these 1961 amendments were repealed in 1963, but property settlement agreements made while they were in effect remain, of course, subject to their provisions, with reference to legislative changes in marital property control rules. The 1959 legislation relating to child support is still in effect.

The 1961 amendment with reference to there heing no minor children of the partics did not indicate whether this limitation on the court's modification power applied only (1) at the time the contract was entered into, or (2) only at the time that the contract 
The court then expressly disapproved a number of appellate decisions but did not include its own earlier case of Miller v. Superior Court in the hist of discredited authorities. Instead, as has been said, it purported to find Miller authority sustaining its own position.

Miller v. Superior Court, ${ }^{108}$ which Bradley effectually disposed of, had been a petition for writ of review to restrain further prosecution of a contempt proceeding, the petitioner contending that he was not subject to such proceedings because his obligation to make monthly payments rested on a property settlement agreement, rather than on a decree for alimony. The agreement had been incorporated and merged in a divorce decree, and the court had expressly ordered the agreed payments to be made.

The supreine court had stated:

There are several decisions of the District Courts of Appeal which have upheld contempt proceedings where the decree, in addition to approving a property settlement, expressly or impliedly orders the defendant to make payments in accordance therewith. . . . Petitioner contends that in the light of certain decisions of this court involving allied questions, the above decisions of the appellate courts recognizing enforcement by contempt proceedings of orders to make monthly payments based on property agreements should be repudiated. . . . A property settlement agreement where the wife is the innocent party and hence entitled to alimony represents an effort by the parties to fix the amount to be paid by the husband as a substitute for, and in compensation for, the marital support which the wife loses through no fault of her own, and in some cases, also in lieu of a share in the community property which the wife who procures a divorce is by statute entitled to have set aside to her. "Such contracts ... derive their sanction from a decree [approving the settlement] made by the court with knowledge of all the facts." (Moog v. Moog, 203 Cal. 406, 408.) . . To support contempt proceedings there inust be an order to pay, express or necessarily to be implied. We do not hold herein that a mere approval of a property settlement, with nothing further, is such an order.... Where the court makes an order to pay, as in the instant case, we are of the view that it may properly be said to have made an "allowance to the wife for her support" within the mearing of section 139 of the Civil Code. Although in this situation the court does not have power to modify the order in the absence of agreement of the parties, since the order also approved the property agreement ... where the parties subsequently make a valid agreement for a lesser amount, as in the case herein, the court, under the power to unodify given by section 139 , may bring its order into line with said subsequent agreement. ${ }^{107}$

was incorporated in a court decree, or (3) at any time in the lifetime of the parties. If the last mentioned, the court would lose its modification powers whenever the children of the parties had all reached their majority. No case has as yet clarified this.

1009 Cal. 2d 733, 72 P.2d 868 (1937).

107 Id. at 738-40, 72 P.2d at 871-72. (Emphasis added.) 
All of the issues raised in Bradley thus had been argued in Miller. Indeed, as Chief Justice Traynor pointed out in his dissent, even the authorities from another jurisdiction relied upon in Bradley were the same cases that had been argued as supporting the unconstitutionality contentions in Miller and there rejected as unsound. ${ }^{108}$ For twenty years California practitioners liad been drawing integrated agreements and having them merged in divorce decrees in reliance on the supreme court's lolding in Miller that the contempt process was a proper enforcement weapon. Yet only Chief Justice Traynor protested the discard of the Miller ruling.

The majority opinion concedes that an alimony award based on the agreement of the parties is enforceable by contempt . . . since it is sufficiently related to the statutory duty of support incident to the marriage relationship as to be outside the constitutional prohibition of imprisonment for debt. ... Rights and duties with respect to property growing out of the marriage relationship and crystallized in a court order are likewise outside the scope of that provision. Such an order has not less a special character because it is based on an agreement of the parties than an alimony award based on such an agreement. Indeed, in some states the very theory imderlying use of contempt to enforce awards of alimony is that alimony is itself an adjustment of property rights. . . . West v. West, 126 Va. 696. . . .

Even if the statutory duty of support were the sole justification for enforcing such court orders by contempt, the majority opinion would still be in error. . . . 109

He then invoked his own analysis from the Dexter case of the "dual" nature of the support and maintenance payments in an integrated agreement, concluding, "So long as the wife has not remarried, the characteristics of the support and maintenance obligation remain and alone justify enforcement by contempt. Such a rule is implicit in the Miller case, where the court took care to point out that the payments were pursuant to a property settlement and could not be changed without the consent of the parties."110

It is worth a comment that even that determined dissenter Justice Carter had never suggested that the contempt process was in any way

108 Id. at 739, 72 P.2d at 872. The court there stated: "Cases from other jurisdictions, such as Dickey v. Dickey, 154 Md. 675, 141 Atl. 387, 58 A.L.R. 634, and Bushman v. Bushman, $157 \mathrm{Md}$. 166, $145 \mathrm{Atl} .488$, to the effect that an order to pay in accordance with the agreement of the parties is not enforceable by process for contempt, are in conflict with the holdings of the appellate courts of this state, which declare a sound rule." Miller v. Superior Court, 9 ,Cal. 2d 733, 739-40, 72 P.2d 868, 872 (1937). Compare this statement in Miller with the Bradley opinion's approving reference to these same cases, $48 \mathrm{Cal} .2 \mathrm{~d} 509$, 519,310 P.2d 634, 640 (1957).

109 Bradley v. Superior Court, 48 Cal. 2d 509, 523-25, 310 P.2d 634, 643 (1957).

110 Id. at $524-25,310 \mathrm{P} .2 \mathrm{~d}$ at 643 . 
unsuitable as a method of enforcing the merged integrated agreement. Indeed, in several dissents, he had expressly or impliedly stated the contrary. ${ }^{111}$

One year after the Bradley decision the supreme court extended the unconstitutionality doctrine even beyond that which it had laid down in Bradley. In Plumer v. Superior Court ${ }^{112}$ petitioner sought relief from a sentence for contempt imposed on him for failure to make certain payments for the support of his former wife and his child in accord with an integrated property settlement agreement. Petitioner, on the basis of the Bradley decision, contended that he was being unconstitutionally held in contempt. The supreme court, speaking through Justice Spence, agreed and annulled the contempt judgment:

While the "plain language" of their agreement indicated that "the parties contemplated modification upon an adequate showing of changed circumstances," there was the express limitation to the effect that the court could not consider an increase in the wife's income as "a changed condition" unless her income exceeded "the inonthly average of $\$ 250 " . .$. [P] etitioner's obligations . . . are contractual and negotiated as distinguished from marital and law-imposed, and therefore the enforcement of such payments by contempt proceedings is precluded by the constitutional prohibition against imprisonment for debt. . . . .113

Again, Chief Justice Traynor was the lone dissenter. Referring once more to the Dexter case exposition of the dual nature of the support payments in integrated property settlement agreements, he distinguished Bradley and continued:

I dissent. My views with respect to the enforcement of integrated bargains by contempt proceedings are set forth in a dissenting opimon in Bradley v. Superior Court .... Although these views remain unchanged, I would concur in the judgment herein under the compulsion of that case if it necessarily controlled the present one.

The present case, however, differs from the Bradley case in that plaintiff has not remarried and the payments are partly for child support. Accordingly, the payments are partly in lieu of the statutory obligation to support. In integrated bargains the monthly payments will ordinarily lave a dual character. ... So long as the wife has not remarried or there is a continuing obligation of child support, the characteristics of the obligation to support remain and alone justify enforcement by contempt. Such a rule is implicit in Miller v. Superior

İ1 Flynn v. Flynn, 42 Cal. 2d 55, 64, 265 P.2d 865, 869 (1954); Messenger v. Messenger, 46 Cal. 2d 619, 634 (1956), 297 P.2d 988, 996 (1956); Plummer v. Superior Court, 20 Cal. 2d 158, 163-65, 124 P.2d 5, 8-9 (1942).

11250 Cal. 2d 631, 328 P.2d 193 (1958).

113 Id. at 636,328 P.2d at 195-96. 
Court, 9 Cal. 2d 733, 740, ... where the court took care to point out that the payments were ordered pursuant to a property settlement and could not be changed without the consent of the parties.

A rule that the wife's right to enforce the agreement by contempt terminates only on her remarriage would permit the parties to make a final settlement of all their marital rights without compelling the wife to give up contempt enforcement while she is still dependent on her former husband for support. So long as the Bradley decision remains law, I would adopt such a rule instead of following the Bradley rationale to its logical extreme. .114 $^{114}$

In searching for a probable, or even possible, explanation of the about face decision in Bradley, it occurred to the writer of these comments that the split on the court which began with the Flynn case, became four to three with the Foust case, and thereafter persisted as a pattern, ${ }^{115}$ may have played a part. A continuous division on the same subject throughout a series of cases cannot be a comfortable situation for a review court. The explosive Bradley decision perhaps cleared the air. If so, it was at the cost of crippling a useful unique institution, for it is beyond argument that execution is not a practical method of enforcing the obligation to make recurring support payments. It follows also that because a challenger of its doctrine had to face a majority of six members of the supreme court, the case eliminated for the time being at least, the likelihood of an opportunity for the court to reconsider the constitutional theory which it had espoused in Bradley. There is some hope that it is only "for the time being" in view of the 1963 case of DiMarco $v$. DiMarco. ${ }^{116}$ In this case Justice McComb, writing for the court an opinion concurred in by four justices, found the property settlement agreement before the court an integrated one and stated, citing Dexter:

Where a husband and wife have made provisions for support and maintenance an integral part of their property settlement agreement, the support payments will ordinarily have a dual character. To the extent they are designed to discharge the obligation of support and maintenance, they will ordinarily have the indicia of alimony; but to the extent they represent a division of community property itself, or constitute an inseparable part of the consideration for the property settlement, they are not alimony and accordingly cannot be modified without changing the terms of the property settlement agreement.117

114 Id. at 638-39, 328 P.2d at 197-98. (Emphasis added.)

115 With the same Justices (Carter, Schauer and Shenk) dissenting in three more consecutive property settlement cases.

11660 Cal. 2d 387, 385 P.2d 2, 33 Cal. Rptr. 610 (1963).

117 Id. at 392, 385 P.2d at 5, 33 Cal. Rptr. at 613. 
The dual nature of the support payments provided in the integrated agreement was iterated and reiterated in the pre-Bradley Traynor opinions. It was emphasized in the Traynor dissents in both the Bradley and Plumer cases, and now once more it has been quoted in full in the DiMarco decision. This leads to the conclusion that without mere wishful thinking it can be maintained-or at least be hoped-that sound analysis of this dual nature may lead to the court's reacceptance of the constitutionality of the contempt process as an enforcement procedure for the integrated agreement's support payments.

After all, as had been said ${ }^{118}$ (with apologies to the Chancellor in Iolanthe) of a rule laid down by an authoritative decision:

That settles it, I think you'll find

Unless, of course, I change my mind!

It is not of record that only once can a mind be changed.

\section{ADDENDUM}

Since this Article was submitted, the 1964 Committee of the California State Bar created to survey the problems created by Bradley reported its agreement with predecessor committees (see note 105) that the contempt process is a very effective way of enforcing a support obligation; that it is socially desirable that contempt be available for this purpose; that "only if support orders are law imposed and based on the power of the Court to make such orders, do they become subject to enforcement by contempt and the constitutional questions raised by the Plumer and Bradley cases eliminated."

The committee therefore is sponsoring two bills, A.B. 50 and A.B. 227 to amend Cal. Civ. Code $\S 139$, to provide that support provisions in property settlement agreements when incorporated and merged in the court's decree and ordered to be performed shall be deemed in all cases law imposed obligations resting on the court's power to make such orders, and subject to modification and revocation in the discretion of the court except when the agreement provides otherwise or when the parties stipulate in open court that said orders for support shall not be subject to modification or revocation; and that all such court support orders even if there has been an agreement or stipulation in open court may be enforced by the court by execution, contempt or by such other order or orders as the court may from time to time deem necessary.

This proposal, if enacted into law and if it thereafter successfully meets constitutional challenge, should give litigating spouses the advantages that, with the present wording of Civil Code section 139, were attainable (im pre-Bradley days) only with the integrated agree- 
ment which Chief Justice Traynor, by repetitive patient analysis, not only helped practitioners to draft and the trial bench to implement, but also successfully protected from attacks made upon it, for a number of years, within the court itself. 